\author{
Monika Szymocha \\ Irena Maniecka-Bryta ${ }^{3}$
}

\title{
DETERMINANTS OF SELF-RATED HEALTH OF A WORKING POPULATION
}

\author{
CZYNNIKI WPŁYWAJĄCE NA SAMOOCENĘ STANU ZDROWIA OSÓB PRACUJĄCYCH
}

\author{
${ }^{1}$ Medical University of Lodz / Uniwersytet Medyczny w Łodzi, Łódź, Poland \\ Chair of Social and Preventive Medicine, Social Medicine Department / Katedra Medycyny Społecznej i Zapobiegawczej, \\ Zakład Medycyny Społecznej \\ ${ }^{2}$ Regional Occupational Medicine Centre in Kielce / Wojewódzki Ośrodek Medycyny Pracy w Kielcach, Kielce, Poland \\ ${ }^{3}$ Medical University of Lodz / Uniwersytet Medyczny w Łodzi, Łódź, Poland \\ Chair of Social and Preventive Medicine, Department of Epidemiology and Biostatistics / Katedra Medycyny Społecznej i Zapobiegawczej, \\ Zakład Epidemiologii i Biostatystyki
}

\begin{abstract}
Background: Self-rated health relates to the use of medical help and, as a consequence, determines sick leave in the population of employees. The aim of the study was to analyze the relationship between socioeconomic variables, selected forms of positive health behaviour and subjective evaluation of health in employees. Material and Methods: Five hundred and 99 subjects were included in the study - 331 females and 268 males, aged 18-67, working in the area of the Świętokrzyskie province. The authors' survey questionnaire on the selected elements of the state of health and positive health behavior in life style has been used in the study. Anthropometric measures were carried out. A Chi ${ }^{2}$ test for independence was used in the statistical analysis. In order to evaluate the effect of the selected factors on the self-rated health of the studied subjects the researchers have applied single- and multiple-factor logistic regression. Results: In the multiple-factor logistic regression the features contributing to good or excellent self-rated health were the following: age up to 39 (odds ratio - OR $=4.17 ; 95 \%$ confidence interval $-\mathrm{CI}$ : $1.72-10.10$; $\mathrm{p}<0.002)$, higher education $(\mathrm{OR}=3.01 ; 95 \% \mathrm{CI}: 1.04-8.70 ; \mathrm{p}<0.05)$ and care for health $(\mathrm{OR}=4.77 ; 95 \% \mathrm{CI}: 2.81-8.09 ; \mathrm{p}<0.001)$. Conclusions: Working people with higher education are characterized by a better control over their own health and, consequently, by a better perception of it. Monitoring self-rated health in a working population is an invaluable indicator in the evaluation of health in employees and the need for medical care. Med Pr 2015;66(1):17-28
\end{abstract}

Key words: self-rated health, working population, logistic regression, health care, mortality

\section{STRESZCZENIE}

Wstęp: Samoocena stanu zdrowia stosowana jest w ochronie zdrowia i w konsekwencji wpływa na absencję chorobową populacji pracującej. Celem badania była ocena zależności między zmiennymi społeczno-ekonomicznymi, wybranymi formami zachowań prozdrowotnych a subiektywną oceną stanu zdrowia osób pracujących. Materiał i metody: Badaniem objęto 599 osób - 331 kobiet $(55,3 \%)$ i 268 mężczyzn $(44,7 \%)$ w wieku $18-67$ lat, pracujących na terenie województwa świętokrzyskiego. Narzędziem badania był kwestionariusz zawierający pytania dotyczące stanu zdrowia i zachowań zdrowotnych w zakresie stylu życia. Przeprowadzono pomiary antropometryczne. W analizie statystycznej wykorzystano test niezależności Chi ${ }^{2}$. W celu oceny wpływu wybranych cech na samoocenę stanu zdrowia badanych zastosowano analizę regresji logistycznej jedno- i wieloczynnikowej. Wyniki: W wieloczynnikowej analizie regresji logistycznej cechami istotnie zwiększającymi szansę bardzo dobrej lub dobrej samooceny stanu zdrowia okazały się: wiek do 39 lat (iloraz szans (odds ratio - OR) = 4,17; 95\% przedział ufności (confidence interval - CI): 1,72-10,10; p < 0,002), wykształcenie wyższe $(\mathrm{OR}=3,01 ; 95 \%$ CI: 1,04-8,70; p < 0,05) i dbałość o zdrowie $(\mathrm{OR}=4,77$; 95\% CI: 2,81-8,09; p < 0,001). Wnioski: Pracujące osoby z wykształceniem wyższym mają lepszą kontrolę nad własnym zdrowiem i w konsekwencji lepszą jego percepcję. Konieczne jest monitorowanie samooceny stanu zdrowia pracujących jako istotnego wskaźnika oceny stanu zdrowia pracowników i zapotrzebowania na opiekę medyczną. Med. Pr. 2015;66(1):17-28

Słowa kluczowe: samoocena stanu zdrowia, populacja pracujących, regresja logistyczna, opieka zdrowotna, umieralność

Corresponding author / Autor do korespondencji: Marek Bryła, Medical University of Lodz,

Chair of Social and Preventive Medicine, Social Medicine Department, Żeligowskiego 7/9, 90-752 Łódź, Poland, e-mail: marek.bryla@umed.lodz.pl

Received: 2014, September 29, accepted: 2014, October 2 


\section{INTRODUCTION}

Self-rated heath includes a subjective evaluation of an individual's physical, mental and social health as well as information gathered from medical examinations and other people's opinions [1]. The data gathered by the Main Statistical Office during the European Health Survey 2009 confirms that Poles' subjective evaluation of health has improved. In 2004, the proportion of people who considered their health unsatisfactory was 39\%, whereas in 2009 this proportion decreased to $34 \%$. The greatest improvement is visible in the respondents aged 40-60. Unfortunately, the results of the study confirm that the percentage of people considering their health unsatisfactory is relatively high and the Świętokrzyskie province is such a region [2].

Self-rated health is an invaluable indicator used to measure an individual's current health as well as serves as a predictor for future potential problems. Studies carried out both in Poland and all over the world indicate that there is a relationship between self-rated health and many other factors such as sex, age, level of education, social and economic factors, concomitant diseases, smoking nicotine, and risks of coming down with non-communicable diseases or external causes of death [3-8]. It very often refers to job stress $[9,10]$. Results of the studies confirm that self-rated health remains not only an essential and reliable indicator of health of a population but is also a crucial morbidity and mortality predictor. It plays a role in assessing the need for medical care [11-16].

The results of the Manitoba Longitudinal Study on Ageing (MLSA) indicate that self-rated health may closely affect mortality rate, irrespective of objective health indicators [17]. Personal life experiences and thoughts about surrounding changes happening in the social, professional and family environment of the individual affect the self-evaluation of health in every aspect. Having analysed dramatic changes in the social and economic situation of employees, taking place over recent decades and resulting from a political system transformation, the authors of the study have attempted to identify factors affecting self-rated health of employees.

The aim of the study is to identify variables affecting the self-rated health of employees. Logistic regression analysis has been used to assess the influence of the studied factors.

\section{MATERIAL AND METHODS}

Five hundred and 99 subjects were included in the study - 331 females (55.3\%) and 268 males (44.7\%), working in the area of the Świętokrzyskie province. They took part in prophylactic examinations from June to December 2009 in the Regional Occupational Medicine Centre in Kielce and in a primary unit of occupational medicine service (Niepubliczny Zakład Opieki Zdrowotnej „Medycyna Pracy \& Medycyna Rodzinna" - Private Health Care Centre "Occupational Medicine \& Family Medicine") within its remit, chosen randomly in an independent way. We received an approval of the Bioethical Committee of the Medical University of Lodz to conduct this study (no. RNN/371/09/KB of 12 May 2009). Participation in our study was optional and each study subject provided a written consent.

The tool of the study was the authors' own survey questionnaire. The respondents were asked to give information on the selected elements of their health and positive health behaviour in the life style. They also evaluated their own health according to a 5-point scale (excellent, good, average, poor, very poor). The researchers measured arterial blood pressure and a set of anthropometric features comprising body weight $(\mathrm{kg})$, body height $(\mathrm{cm})$ and analysed Body Mass Index (BMI) following procedures recommended by European scientific societies.

\section{Statistical analysis}

Regarding the statistical analysis, the following values were calculated for measurable characteristics: arithmetic mean $(\mathrm{M})$, median $(\mathrm{Me})$, modal value $(\mathrm{Mo})$ and the coefficient of variance (v\%). Minimum and maximum values were also given. The $\mathrm{Chi}^{2}$ test for independence was also used to compare the frequency of characteristics in the studied groups as well as to analyse the relationships between the characteristics. The significance level was $p<0.05$.

A coefficient of rectilinear correlation ( $r$ ) was used to analyse the relationship between the measurable characteristics, and t-student test was applied to analyse its significance. The structure rates for small groups were given in fractions and for large groups a percentage value was given. To evaluate the potential influence of selected social and demographical factors as well as particular behaviours affecting self-rated health, the authors of the study applied single- and multiple-factor logistic regression. The Statistica v.9.0 software package was used for statistical purposes. It is worth noting that the analysis was conducted with the use of 3 models: 
very good and good self-rated health vs. average and poor ones,

average self-rated health vs. very good and poor ones,

poor self-rated health vs. very good, good, and average ones.

\section{RESULTS}

Table 1 presents the studied group characteristics, location and dispersion of particular characteristics. The studied group included respondents aged 18-67. The mean age was $45.8 \pm 10.4$; the median age was 48.0 and the modal was 52 . Majority of the subjects were aged 50-59 (38.2\%). The analysis confirms that most of them (63.8\%) do mental work. A statistically significant difference between the sexes was observed in this aspect (81\% females, $42.5 \%$ males $)-\mathrm{Chi}^{2}=94.666 ; \mathrm{p}<0.001$. Majority of the studied subjects (74\%) work fixed hours. It appears that females $(77.6 \%)$ work fixed hours significantly more often than males $(69.4 \%)-\mathrm{Chi}^{2}=5.221 ; \mathrm{p}<0.05$.

A statistically significant difference has also been noted with regard to the sector they work for $\left(\mathrm{Chi}^{2}=89.337\right.$; $\mathrm{p}<0.001$ ). Women work mostly in industry/production, administration and education $(26 \%, 17.5 \%, 15.1 \%)$. With regard to men, the highest percentage work in industry/ production (52.0\%) and administration (12.7\%). The studied subjects have had long professional work experience; $2 / 3$ of them have worked for longer than 20 years. A significant relationship between the number of years worked and the sex was observed $\left(\mathrm{Chi}^{2}=9.936 ; \mathrm{p}<0.05\right)$. In our study sample, $71.3 \%$ of males and $64.3 \%$ of females have worked for longer than 20 years.

The subjects included in the study were asked to make their health self-evaluation. The greatest number of respondents (53\%) consider their health good. The 2nd biggest group regard their health as average (37.2\%). A statistically significant relationship has also been noted between self-rated health and the age of the subjects $\left(\mathrm{Chi}^{2}=80.716 ; \mathrm{p}<0.001\right)$. It turns out that the older the respondent is, the less frequently he/she considers his/her health to be excellent. It is significantly average or even poor. The self-rated health is also significantly related to the respondents' level of education $\left(\mathrm{Chi}^{2}=29.741 ; \mathrm{p}<0.01\right)$. The better educated the respondent is, the more often he/she considers his/her health to be good or excellent. Those less educated claim their health is average.

Kind of work turns out to affect a subjective health assessment of $\left(\mathrm{Chi}^{2}=9.645 ; \mathrm{p}<005\right)$. Those who perform mental work, rather than physical employees, significantly more often claim that their health is good $(57.4 \%$ vs. $45.2 \%)$. The group of manual workers most often consider their health to be average ( $44.7 \%$ vs. $33.0 \%)$. There is no relationship between self-rated health and the kind of work (i.e., fixed-time or shift work) $-\mathrm{Chi}^{2}=2.471 ; \mathrm{p}>0.05$.

The analysis has not confirmed there is a significant relationship between self-rated health and a professional position in the workplace $\left(\mathrm{Chi}^{2}=2.770 ; \mathrm{p}>0.05\right)$. However, the number of years worked significantly affect the subjects' self-rated health $\left(\mathrm{Chi}^{2}=62.849 ; \mathrm{p}<0.001\right)$. The longer the subject has worked, the more often his/her health is considered significantly average, the less frequently - excellent. No statistical significance has been observed between self-rated health and the economic situation of the respondents $\left(\mathrm{Chi}^{2}=8.256 ; \mathrm{p}>0.05\right)$.

A statistically significant relationship was also noted between the sector the respondent works in and self-rated health $\left(\mathrm{Chi}^{2}=32.579 ; \mathrm{p}<0.01\right)$. Employees from education and services sectors have most positively evaluated their health (notes "good" and "excellent" constitute 0.7 of the total number of notes). Those working in the transport sector and in the industry/ production sector claim their health is unsatisfactory ( 0.45 and 0.53 respectively). Self-evaluation of health with regard to those who work in 1 or more than in 1 place is similar $\left(\mathrm{Chi}^{2}=3.025 ; \mathrm{p}>0.05\right)$. However, it should be pointed out that the respondents who are employed in 3 or more places more often considered their health to be excellent ( 0.16 in comparison with 0.07 , i.e., those working in 2 places and 0.06 , i.e., those working in 1 place) or good $(0.63,0.53,0.53$, respectively).

The analysis also confirmed a relationship between care for health and self-rated health of the studied subjects $\left(\mathrm{Chi}^{2}=78.768 ; \mathrm{p}<0.001\right)$. Those who care for their health significantly regard it as better than those who do not care about physical well-being or do not hold any opinion on healthy lifestyle. Moreover, their self-rated health is related to the frequency of seeking medical help $\left(\mathrm{Chi}^{2}=53.404 ; \mathrm{p}<0.001\right)$. The respondents who less frequently use medical services consider their health to be better. There is a slightly significant relationship between self-rated health and using medical services performed by a family doctor, specialist medical centre or by both of these 2 ( $p<0.001)$. It can be concluded that those who use these 2 mentioned medical services significantly more often with regard to their health as average $(45 \%)$ or poor (13\%). More than half of the respondents who visit a family doctor claim their health is good (56\%) or excellent (8\%). 


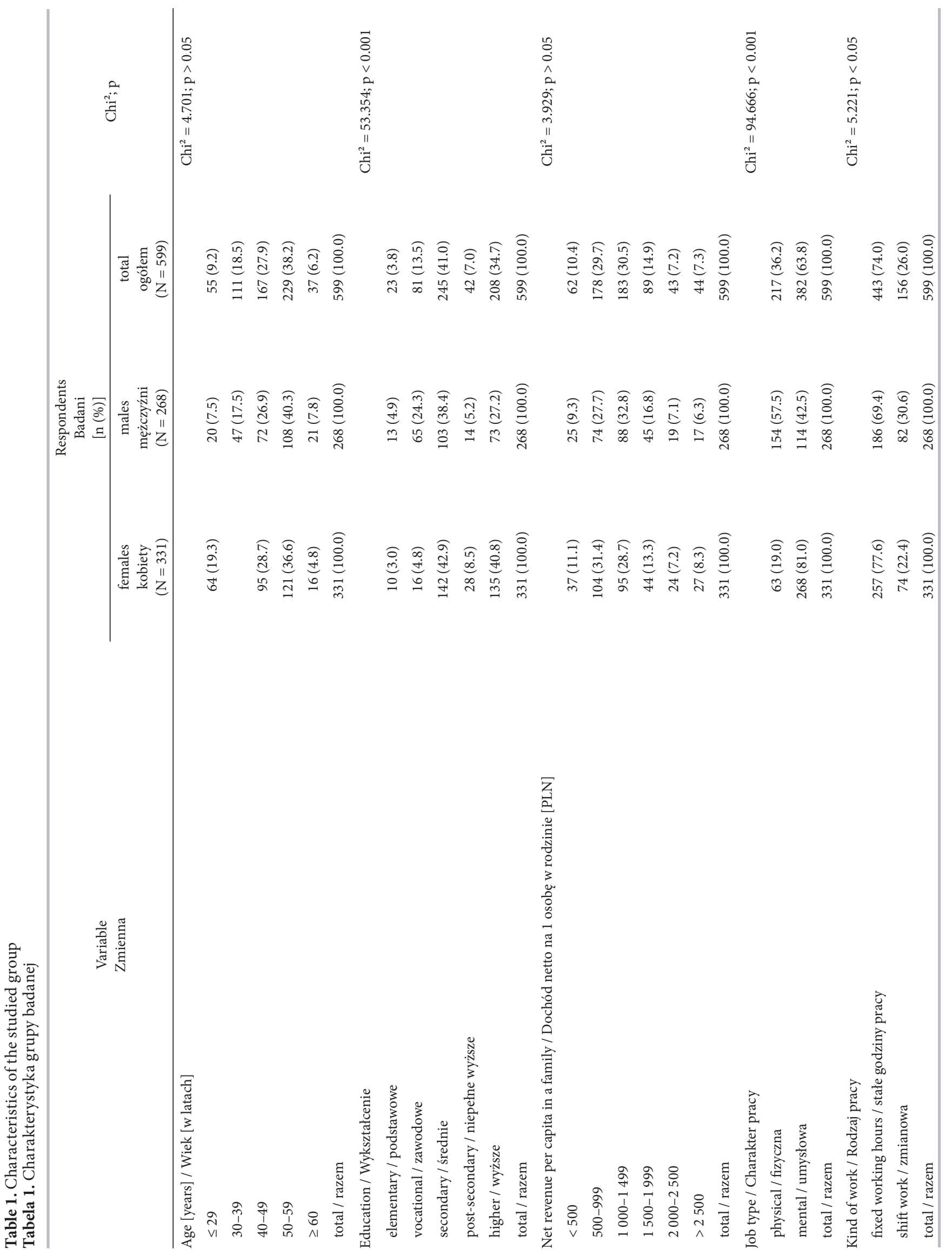



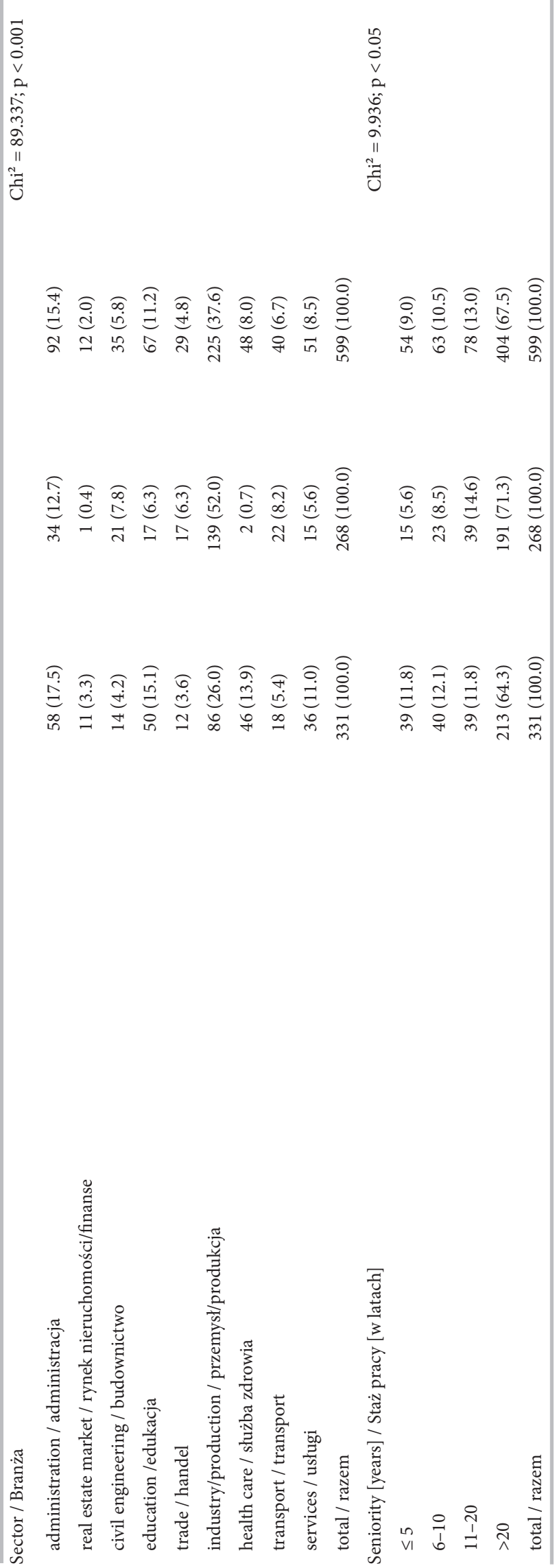

Self-rated health is an indicator which refers to physical, mental and social aspects of health. The authors of this study have attempted to evaluate the influence of selected variables on this important health indicator. In the logistic regression, the following variables were taken into consideration: sex, age, education, kind of work, work position, number of working hours, economic situation, care for health, physical activity, smoking nicotine and BMI index. The mentioned variables have been put into categories: social and demographic factors, workrelated factors, positive behaviour-related factors.

The results of the conducted single-factor logistic regression confirm that people at the age of 29 or younger are 3 times more likely to consider their health to be good or excellent than people aged 60 or older (odds ratio $(\mathrm{OR})=3.39$ ). The chance for a positive self-evaluation is even greater at the age between 30 and $39(\mathrm{OR}=3.62)$ (Table 2). Higher education also increases the chances 3 times $(\mathrm{OR}=3,62)$ in comparison to the respondents with elementary education.

Those who perform mental work state 1.5 times more often that their health is good or excellent in comparison with those who do physical work. Care for health increases the chances 4.5 times. Subjects who are physically active regard their health as good or excellent more than twice as often as those who are sedentary. This positive self-evaluation refers also to those who rarely do any sports. Also BMI remains regular in those physically active $(\mathrm{OR}=1.73)$.

All of the variables from the single-factor analysis which significantly affect self-rated health have been used in the multi-factor analysis. In the multifactor analysis of logistic regression, only 3 factors have turned out to significantly contribute to good or excellent self-evaluation of health. They are: age, level of education and care for health (Table 3). Those aged 29 or younger consider their health to be good or excellent $(\mathrm{OR}=3.64) 3.5$ times more often than those aged 60 or older. Those at the age 30-39 make an even more positive self-evaluation. They regard their health as good or excellent 4 times more often $(\mathrm{OR}=4.17)$. With regard to the level of education, chances for a positive self-evaluation are 3 times higher in people who enjoy higher education in comparison to those with only elementary education $(\mathrm{OR}=3.01)$. With regard to care for health, chance for a positive self-evaluation is 5 times higher in people who care about their health in comparison to those who neglect their health. The remaining factors have not significantly contributed to good or excellent self-evaluation of health. 


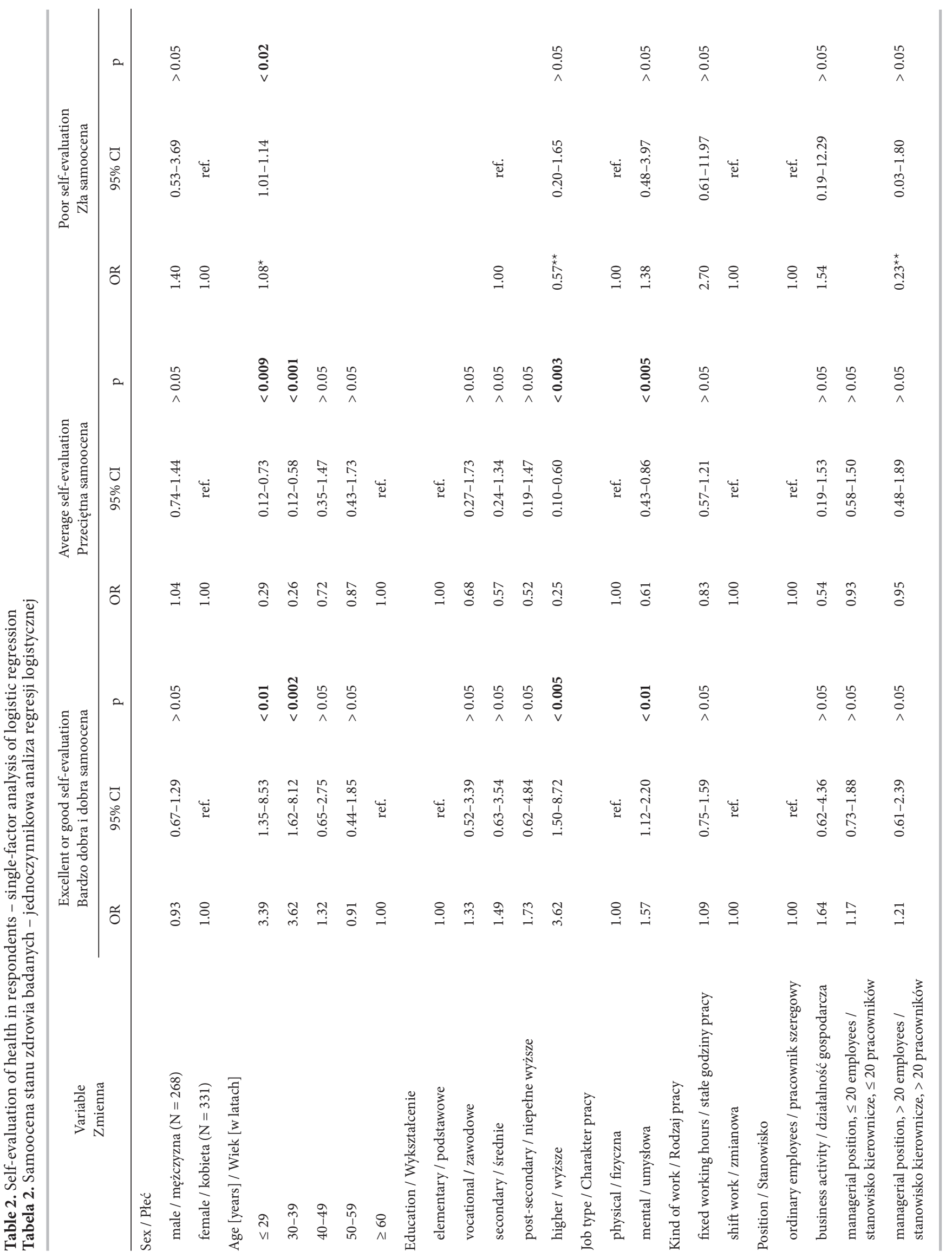




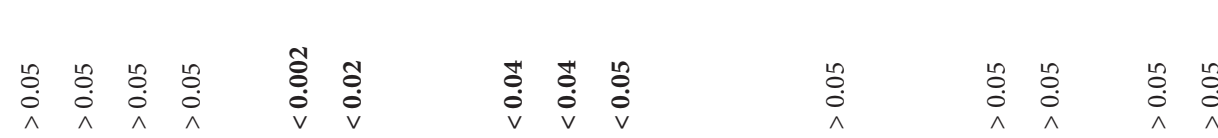

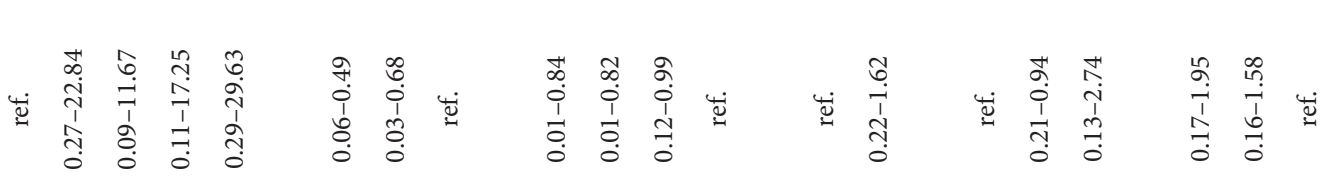

芹

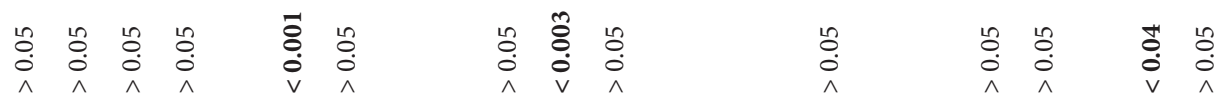

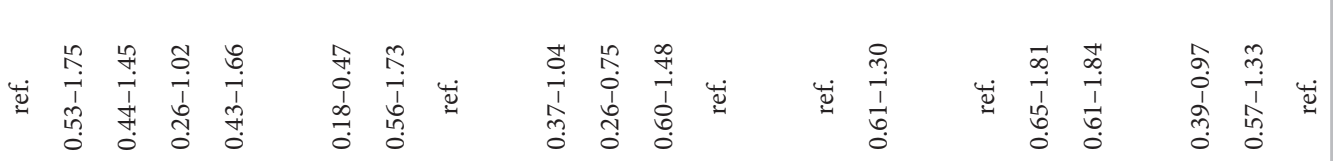

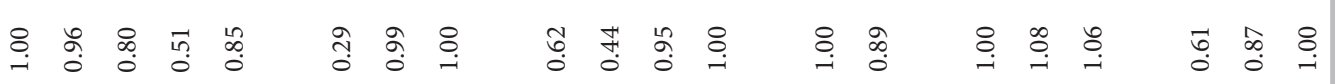

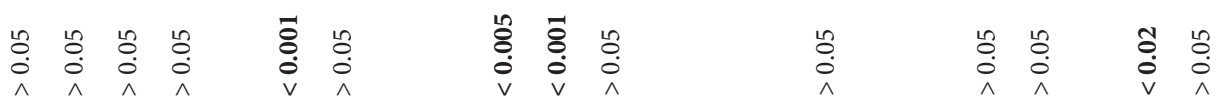

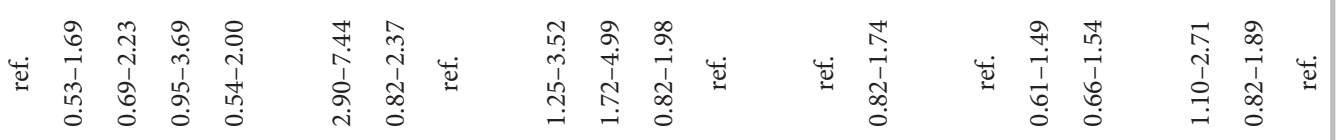

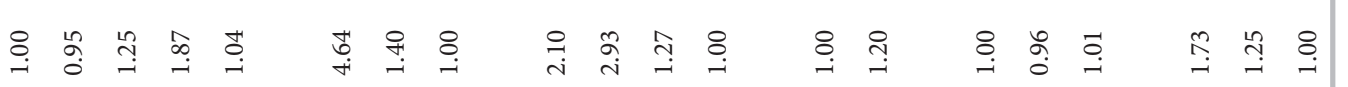




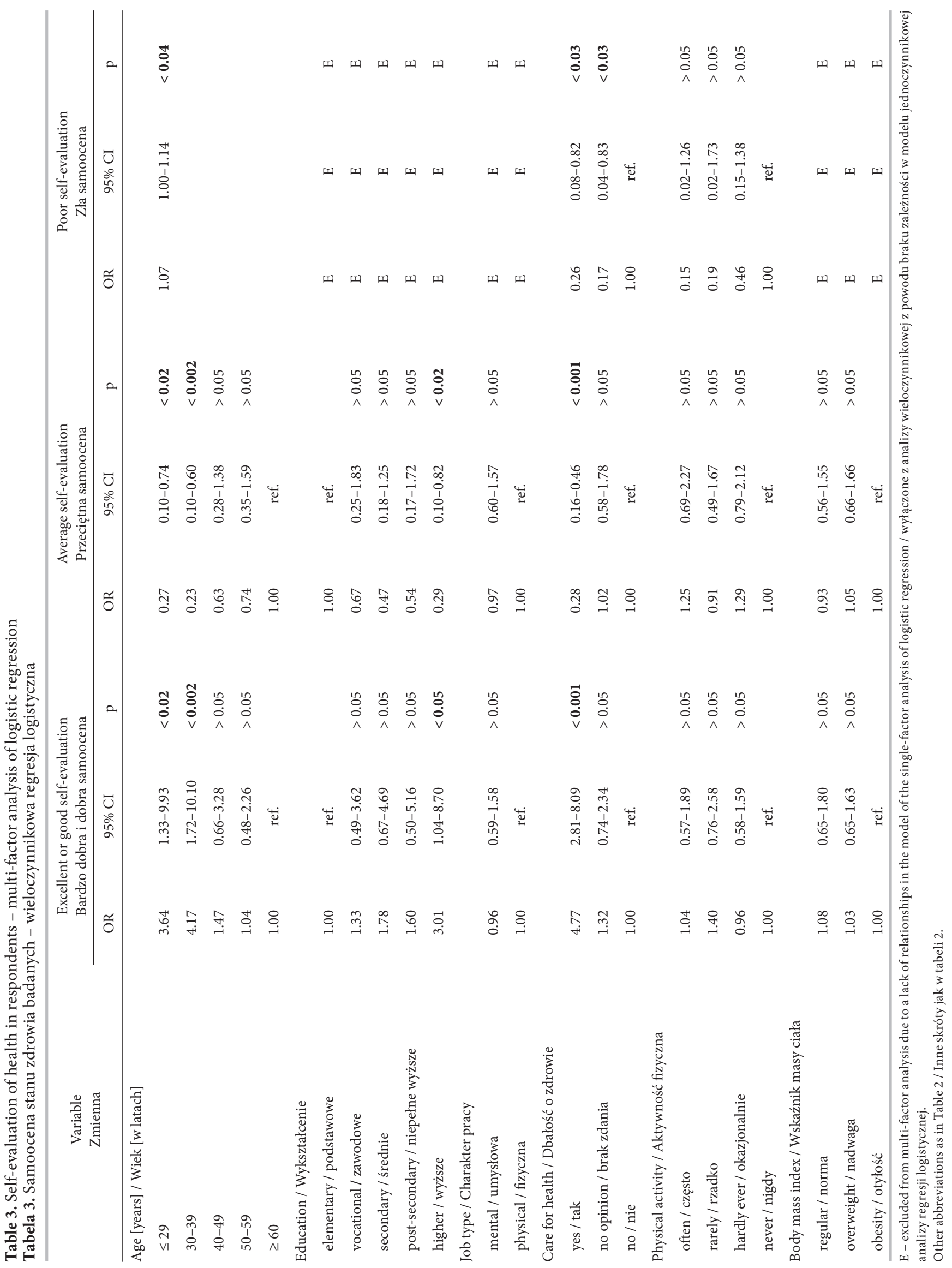




\section{DISCUSSION}

Professional literature shows that self-rated health plays a crucial role in the evaluation of health and health inequalities. The results of a study conducted in Greece by Alexopoulos et al. on a group of 1000 subjects indicate that $20.8 \%$ of males and $37.2 \%$ of females regard their health as unsatisfactory. It is strongly related to sex, age insurance coverage and chronic diseases [12]. A similar observation has been made in the authors' own study in which the respondents' age and education affected their health. Among our study subjects, $40 \%$ considered their health to be unsatisfactory.

A higher percentage of women regarding their health as unsatisfactory has also been observed in Syria in a study conducted on a group of people aged 18-65. Age and concomitant diseases in both males and females, marital status, low social and economic status and lack of support in females as well as smoking and almost no physical activity in males contributed to such an unsatisfactory self-evaluation [18]. In the presented study, rare visits to medical doctors went along with a more positive evaluation of health.

In the study called Behavioural Risk Factor Surveillance System (BRFSS) conducted by Kawachi et al. on a group of 167259 subjects in the United States, 84.9\% of the studied respondents have claimed their health is excellent, very good or good $(24.3 \%$; $33.3 \%$; $27.3 \%$, respectively) [19]. Unsatisfactory health state is connected with being Afro-American ethnicity, age, obesity, smoking nicotine, low income, place of residence and low level of education [20-21]. It is also very important to undertake appropriate health policy decisions aiming at the improvement of research capacities of many European countries [22].

The authors of GAZEL (GAZ and ELectricité) studies carried out in France in 1990 on 14696 employees emphasized 4 factors (physical tiredness, a number of health problems in the past year, physical activity and a number of administered drugs) which, in $41.4 \%$ of the respondents, clarified discrepancies in self-rated health. The influence of self-rated health on mortality was getting weaker when the level of education and income were getting higher. The authors of the Whitehall II study conducted in Great Britain between 1985 and 1988 on 10308 respondents presented 6 factors affecting self-evaluation of their health [23]. They included a number of disease symptoms, absenteeism at work in the last year, chronic diseases, minor mental health disorders, a number of serious infections recurring in the last year. The authors also analysed the influence of self-rated health on a mortality rate. Although women more often considered their health unsatisfactory, no differences with regard to sex were observed.

Self-rated health appeared a similar prognostic indicator for mortality both in females and males. It should be emphasized that, in the 2 mentioned studies, the researchers analysed 36 variables divided into 6 categories: age, factors characteristic for a young age, family history, socio-demographic factors, objective measurements of the individual's health state and diseases, positive behaviours and psychosocial factors [23]. Idler et al., in their NHANES I (National Health and Nutrition Examination Survey) epidemiologic follow-up study, confirmed that unsatisfactory self-rated health contributes to an increased mortality rate [24].

McFadden et al. included in their study 22457 British people aged 39-79 [14]. They also confirmed there is a relationship between self-rated health and the social status of an individual. Physical employees from all age groups, more often than employees who perform mentally challenging work, claimed that their health is unsatisfactory or poor [14]. This study has also confirmed that mentally working employees more positively evaluate their health than physical employees $(\mathrm{p}<0.05)$.

Numerous studies point out that age plays an important role in a positive assessment of health. Kivinen et al., in their study conducted on a group of male subjects, aged 70 and above, demonstrated that only $20 \%$ of the respondents positively evaluate their health [11]. A meta-analysis, performed by Kondo et al. on the basis of 28 trials comprised a group of 59509857 subjects. The results of the meta-analysis indicate that people inhabiting regions in which there are high inequalities in income demonstrate an increased risk of premature death and regard their health as less satisfactory [25].

In a study conducted by Bobak et al. in a group of Russian inhabitants, subjective evaluation of health included personal autonomy, low income, reaction to some economic changes and social networks [26]. A study by Weich et al. proved there is a correlation between low income and negative self-evaluation of health [27].

A study conducted in Poland on people aged 65-74 confirms that almost every 3 rd person (29.2\%) perceives his/her health as poor. Higher level of education of individuals contributed to making a positive self-evaluation of health (OR $=1.85$; 95\% CI: 1.29-2.65; $\mathrm{p}<0.001)$, $\mathrm{BMI}<25.0(\mathrm{OR}=2.32 ; 95 \% \mathrm{CI}: 1.54-3.51 ; \mathrm{p}<0.001)$, 
infrequent seeking medical help in a year $(\mathrm{OR}=3.00$; 95\% CI: $1.99-4.55 ; \mathrm{p}<0.001)$ and not suffering from diabetes $(\mathrm{OR}=1.85)$, coronary disease $(\mathrm{OR}=1.45)$ and arterial hypertension $(\mathrm{OR}=1.64)$. A positive tendency was also observed in 1991-2002. It appeared to accompany political changes, as in 1991 only 21.55 of the respondents claimed they enjoy good health and in 2002 the percentage increased to $40 \%$ [28].

A similar tendency was noted in a Pol-MONICA Warszawa study conducted in 1984-2001. The percentage of people regarding their health as satisfactory, if not even very poor, dropped and this tendency was much more visible in females. Yet, despite this falling trend, in 2001 , as many as $45 \%$ of females and $41 \%$ of males still negatively perceived their health. The determining factors were age, level of education, physical activity, concomitant diseases, especially diabetes and myocardial ischaemia. Similarly to this study, smoking nicotine did not contribute to a negative self-evaluation of health [29].

An analysis of logistic regression made in another Polish study confirms that low income and poor education level significantly affect self-rated health. There is a risk of a negative self-evaluation of health. Body weight has appeared to be an insignificant variable for males and significant for females. Women whose body weight was normal stated that their health is good [30]. With regard to the single-factor analysis, young age, high level of education, mental work, care for health, physical activity and regular BMI contributed to an increased chance of considering health good or excellent. In the multi-factor analysis, only 3 variables played a positive role and contributed to an increased positive perception of health. The factors included age up to 39, a high level of education and care for health.

In regression models, we found no impact of male sex on very good and good self-rated health odds, which may be connected with the more numerous group of females under study as well as their better level of education. Moreover, there was no impact of the economic situation on the perception of one's health, which may be explained by the fact that family per capita income data was provided by the study subjects themselves and were not verified with payrolls due to the protection of personal data.

We observed no impact of the job character (white collar - blue collar) and type (fixed working hours shift work) on good self-rated odds in the multivariate logistical regression model, although these variables were significant in the bivariate logistical regression model, which may be related to the size of the study sample. Undoubtedly, this is a limitation of our study, which results from the volume of funding. We are aware of the above mentioned limitations.

\section{CONCLUSIONS}

1. The following variables turned out to be strong modifiers of self-rated health in the working population under study: age, education level and care for one's health, which stems from a better control over one's health among people with a higher education level.

2. It is necessary to monitor the health status of the working population as an important indicator of the health situation and the consequent demand for health care.

Issues related to the self-rated health of the working population in Poland have rarely been subject to research. Therefore, each contribution in this field extends, deepens, and disseminates this scarce and valuable knowledge. Our findings demonstrate the impact of the following factors on the self-rated health of the working population in Poland: age, education, work experience and declared self-care for health. Our results may be useful to health policy decision-makers, especially in the post-communist economies which have undergone radical systemic transitions.

\section{REFERENCES}

1. Nowak M. [Self-rated health and physical fitness among females and their participation in control medical examinations]. Nowa Med. 1999;7:45-8. Polish.

2. Central Statistical Office. [European Health Survey in 2009, Department of Social Studies Accessed] [cited 2012 Feb 1]. Available from: http://stat.gov.pl/cps/rde/ xbcr/gus/POZ_eur_ank_bad_zdr_2009.pdf. Polish.

3. Taimela S, Läärä E, Malmivaara A, Tiekso J, Sintonen H, Justén S, et al. Self-reported health problems and sickness absence in different age groups predominantly engaged in physical work. Occup Environ Med. 2007;64(11): 739-46, http://dx.doi.org/10.1136/oem.2006.027789.

4. Bryła M, Maciak-Andrzejewska A, Maniecka-Bryła I. [Job-dependent prevalence of selected risk factors for cardiovascular diseases in the prevention program participants]. Med Pr. 2013;64(3):307-15, http://dx.doi. org/10.13075/mp.5893.2013.0026. Polish.

5. Maniecka-Bryła I, Maciak-Andrzejewska A, Bryła M, Bojar I. An assessment of health effects of a cardiological prevention programme in a local community with the 
use of the SCORE algorithm. Ann Agric Environ Med. 2013;20(4):794-9.

6. Pikala M, Kaleta D, Bielecki W, Maniecka-Bryła I, Drygas W, Kwaśniewska M. Awareness of cardiovascular prevention methods among residents of post-communist Polish provinces with highest mortality rates. Cent Eur J Public Health. 2011;19(4):183-9.

7. Maniecka-Bryła I, Pikala M, Bryła M. [Life years lost due to cardiovascular diseases]. Kardiol Pol. 2013;71(10): 1065-72, http://dx.doi.org/10.5603/KP.2013.0262.

8. Pikala M, Bryla M, Bryla P, Maniecka-Bryla I. Years of life lost due to external causes of death in the Lodz province, Poland. PLoS One. 2014;9(5):e96830, http://dx.doi. org/10.1371/journal.pone.0096830.

9. Oxenstierna G, Magnusson Hanson LL, Widmark M, Finnholm K, Stenfors C, Elofsson S, et al. Conflicts at work - The relationship with workplace factors, work characteristics and self-rated health. Ind Health. 2011;49(4): 501-10, http://dx.doi.org/10.2486/indhealth.MS1171.

10. La Rosa-Rodriguez E, Le Clesiau H, Dubois G, Izard JL, Bonin M, Bordron J, et al. [Assessment of work-related stress following implementation of preventive measures in a pension fund]. Santé Publique 2013;25(1):59-67 [cited 2014 Oct 28]. Available from: http://www.cairn. info/revue-sante-publique-2013-1-page-59.htm. French.

11. Kivinen P, Halonen P, Eronen M, Nissinen A. Self-rated health, physician-rated health and associated factors among elderly men: The Finnish cohorts of the Seven Countries Study. Age Ageing. 1998;27(1):41-7, http://dx. doi.org/10.1093/ageing/27.1.41.

12. Alexopoulos EC, Geitona M. Self-rated health: Inequalities and potential determinants. Int J Environ Res Public Health. 2009;6(9):2456-69, http://dx.doi.org/10.3390/ ijerph6092456.

13. Maniecka-Bryła I, Dziankowska-Zaborszczyk E, Bryła M, Drygas W. Determinants of premature mortality in a city population: An eight-year observational study concerning subjects aged 18-64. Int J Occup Med Environ Health. 2013;26(5):724-41, http://dx.doi.org/10.2478/ s13382-013-0154-7.

14. McFadden E, Luben R, Bingham S, Wareham N, Kinmonth AL, Khaw KT. Social inequalities in self-rated health by age: Cross-sectional study of 22457 middleaged men and women. BMC Public Health. 2008;8:230, http://dx.doi.org/10.1186/1471-2458-8-230.

15. Pikhart H, Bobak M, Siegrist J, Pajak A, Rywik S, Kyshegyi J, et al. Psychosocial work characteristics and self rated health in four post-communist countries. J Epidemiol Community Health. 2001;55(9):624-30, http://dx.doi.org/10.1136/jech.55.9.624.
16. Maniecka-Bryla I, Szymocha M, Bryla M. Overweight and obesity as risk factors in hypertension - Study of the working population. Med Lav. 2011;102(6):523-38.

17. Mossey JM, Shapiro E. Self-rated health: A predictor of mortality among the elderly. Am J Public Health. 1982;72(8):800-8, http://dx.doi.org/10.2105/AJPH.72.8.800.

18. Asfar T, Ahmad B, Rastam S, Mulloli TP, Ward KD, Maziak W. Self-rated health and its determinants among adults in Syria: A model from the Middle East. BMC Public Health. 2007;7:177, http://dx.doi.org/10. 1186/1471-2458-7-177.

19. Kawachi I, Kennedy BP, Glass R. Social capital and self-rated health: A contextual analysis. Am J Public Health. 1999;89:1187-93.

20. Maniecka-Bryła I, Gajewska O, Burzynska M, Bryła M. Factors associated with self-rated health (SRH) of a University of the Thirds Age (U3A) class participants. Arch Gerontol Geriatr. 2013;57(2):156-61, http://dx.doi.org/ 10.1016/j.archger.2013.03.006.

21. Bryła M, Burzynska M, Maniecka-Bryła I. Self-rated quality of life of city-dwelling elderly people benefitting from social support: Results of a cross-sectional study. Health Qual Life Outcomes. 2013;11:181, http://dx.doi. org/10.1186/1477-7525-11-181.

22. Burazeri G, Brand H, Laaser U. Public health research needs and challenges in transitional countries of South Eastern Europe. Ital J Public Health. 2009;6(1):48-51.

23. Singh-Manoux A, Gueguen A, Martikainen P, Ferrie J, Marmot M, Shipley M. Self-rated health and mortality: Short- and long-term associations in the Whitehall II Study. Psychosom Med. 2007;69(2):138-43, http://dx.doi. org/10.1097/PSY.0b013e318030483a.

24. Idler EL, Russell LB, Davis D. Survival, functional limitations, and self-rated health in the NHANES I - Epidemiologic follow-up study, 1992. Am J Epidemiol. 2000;152(9):874-83, http://dx.doi.org/10.1093/aje/152.9.874.

25. Kondo N, Sembajwe G, Kawachi I, van Dam RM, Subramanian SV, Yamagata Z. Income inequality, mortality, and self-rated health: Meta-analysis of multilevel studies. BMJ. 2009;339:b4471, http://dx.doi.org/10.1136/ bmj.b4471.

26. Bobak M, Pikhart H, Hertzman C, Rose R, Marmot M. Socioeconomic factors, perceived control and self-reported health in Russia. A cross-sectional survey. Soc Sci Med. 1998;47(2):269-79, http://dx.doi.org/10.1016/S02779536(98)00095-1.

27. Weich S, Lewis G, Jenkins SP. Income inequality and self-rated health in Britain. J Epidemiol Community Health. 2002;56(6):436-41, http://dx.doi.org/10.1136/ jech.56.6.436. 
28. Maniecka-Bryla I, Drygas W, Bryla M, DziankowskaZaborszczyk E. Determinants of self-rated health among the elderly living in a big city environment. Pol J Environ Stud. 2011;20(3):691-9.

29. Sygnowska A, Waskiewicz A. [Self rated health of Warsaw inhabitants between 1984-2001 - trends, determinants. Pol-MONICA study]. Nowiny Lek. 2006;75(6): 531-6. Polish.
30. Wroblewska W. [Health situation in Poland - the role of socio-economic factors and life style. Assessment on the basis of SRH and PAR indicators]. Zeszyty Nauk Katedry Stat Ekonometrii Wydz Nauk Ekonom. 2010;2:1-28. Polish.

The use of the article "Determinants of self-rated health of a working population" is available in Open Access model and permitted under license conditions of Creative Commons Attribution-NonCommercial 3.0 (also known as CC-BY-NC), available at http://creativecommons.org/licenses/by-nc/3.0/pl/ or another language version of this license or any later version of this license published by Creative Commons / Zezwala się na korzystanie $\mathrm{z}$ artykułu „Czynniki wpływające na samoocenę stanu zdrowia osób pracujących” w modelu open access na warunkach licencji Creative Commons Uznanie autorstwa - Użycie niekomercyjne 3.0 (znanej również jako CC-BY-NC), dostępnej pod adresem http://creativecommons.org/licenses/by-nc/3.0/pl/ lub innej wersji językowej tej licencji, lub którejkolwiek późniejszej wersji tej licencji, opublikowanej przez organizację Creative Commons. 